\title{
Effects of Natural Atlantic Forest Regeneration on Soil Fauna, Brazil
}

\author{
Rodrigo Camara ${ }^{1}$, Gilsonley Lopes dos Santos ${ }^{1}$, Marcos Gervasio Pereira ${ }^{1}$, \\ Cristiane Figueira da Silva ${ }^{1}$, Vanessa Francieli Vital Silva ${ }^{1}$, Rafaela Martins Silva ${ }^{1}$ \\ ${ }^{1}$ Universidade Federal Rural do Rio de Janeiro - UFRRJ, Seropédica/RJ, Brazil
}

\begin{abstract}
The stage of natural forest regeneration may influence soil fauna. This study aimed to test the hypothesis that there are differences in the structure and composition of the soil fauna communities between areas undergoing less advanced (LAS) and more advanced (MAS) stages of natural regeneration of Seasonal Semideciduous Forest at Pinheiral, RJ. Soil fauna was sampled using pitfall traps, during dry and rainy seasons. Total abundance, abundance of the saprophagous/predator group, mainly Formicidae, and the relative participation of Orthoptera were higher in MAS, while the relative participation of Acari, Araneae, Coleoptera, Diptera and the herbivorous group were higher in LAS, during both climatic seasons. Some taxonomic groups were restricted to one of the areas. Richness, evenness and diversity tended to present higher values in LAS (dry season). The higher complexity of the soil fauna community was correlated to the higher leaf litter standing stock in LAS.
\end{abstract}

Keywords: edaphic fauna, bioindicators, forest succession. 


\section{INTRODUCTION}

Logging aims to meet different human needs. However, it leads to habitat fragmentation, loss of biodiversity and soil erosion (Siminski et al., 2004). As a result, there are many environmentally vulnerable forest fragments, usually small and with different formats in varying stages of natural regeneration (Caldas \& Francelino, 2009). Depending on the disturbance, history of land use and availability and proximity to forest remnants as sources of propagules, some of the deforested areas can regenerate spontaneously, after been abandoned (Guariguata \& Ostertag, 2001). If this process does not occur spontaneously however, it is necessary to implement measures to accelerate forest regeneration in degraded areas. Edaphic organisms may act as bioindicators to evaluate this process, because the activity of these organisms changes biological, chemical and physical processes occurring in the soil (Snyder \& Hendrix, 2008).

According to some authors, abundance, richness and diversity of soil fauna increases, as secondary succession in tropical forest ecosystems advances (Barberena-Arias \& Aide, 2003; Negrete-Yankelevich et al., 2007; Morais et al., 2010; Menezes et al., 2009; Camara et al., 2012; Szinwelski et al., 2012; Rousseau et al., 2014; Machado et al., 2015). Additionally, the predators and saprophagous are both functional groups that are somehow favored in areas undergoing more advanced stages of forest regeneration (Menezes et al., 2009; Camara et al., 2012; Rousseau et al., 2014; Machado et al., 2015). However, there are divergent results in terms of Formicidae. It has been observed in Brazilian Amazon (Morais et al., 2010) and Atlantic Forests (Menezes et al., 2009; Camara et al., 2012) that the abundance or relative participation of this saprophagous-predator group was higher in areas undergoing a less advanced stage of tropical forest regeneration than a more advanced stage.

By contrast, ants may also be favored in areas at more advanced stages of Atlantic Forest regeneration (Machado et al., 2015). These results demonstrated that areas at different stages of tropical forest regeneration present differences in the structure and composition of their soil organism communities. Therefore, monitoring the soil fauna assembly, which contributes to the carbon and nutrient cycling, helps to evaluate the soil ecological functions of the tropical forest remnants. The present study aimed to test the hypothesis that there are differences in the structure and composition of the soil arthropod communities between two areas of Seasonal Semideciduous Forest at different stages of natural forest regeneration (LAS: less advanced stage; MAS: more advanced stage) at Pinheiral, Rio de Janeiro, Brazil.

\section{MATERIAL AND METHODS}

The study was carried out in the municipality of Pinheiral, located between latitudes $22^{\circ} 29^{\prime} 03^{\prime \prime}$ and $22^{\circ} 35^{\prime} 27^{\prime \prime}$ 'South and longitudes between $43^{\circ} 54^{\prime} 49^{\prime \prime}$ and $44^{\circ} 04^{\prime} 05^{\prime \prime}$ West, State of Rio de Janeiro, Brazil. The climate is classified as Cwa - humid subtropical climate with dry winter and hot summer (Köppen, 1948). The predominant soils are Ultisols Red-Yellow and Inceptsol on the hillside, Oxisols and Red-Yellow both on top and upper third of the slope (Menezes, 2008). The intense transformations of the landscape and soil degradation began more than $180 \mathrm{yr}$ ago, with the establishment of coffee crops in the region. The secondary forest began through natural regeneration at sites undergoing minor human pressure, when this activity ended about $120 \mathrm{yr}$ ago (Menezes, 2008). The original vegetation is Seasonal Semideciduous Forest that belongs to the Atlantic Forest Biome, but nowadays the predominant vegetation cover consists of implanted grasslands and spontaneous unmanaged abandoned grasslands, which generate areas with different stages of natural forest regeneration (Menezes et al., 2009).

Two contiguous areas of this secondary forest fragment at different stages of natural regeneration were selected: less advanced stage of forest regeneration (LAS), represented by a convex pedoform, and more advanced stage of forest regeneration (MAS), which corresponds to a concave pedoform (Santos, 2014). In LAS, the tree species with higher importance value index (IVI) are Pseudopiptadenia contorta (DC.) Lewis and Lima, Apuleia leiocarpa (Vogel) Macbr., Piptadenia gonoacantha (Mart.) Macbr., Senefeldera multiflora Mart., and Matayba guianensis Aubl., while Guarea kunthiana Juss., Hyeronima alchorneoides Allemão, Astrocaryum aculeatissimum (Schott) Burret., Eugenia spp. 1 and Guapira opposita (Vell.) Reitz are the most important species in MAS (Table 1). 
Table 1. Mean values of tree community and soil attributes in the less advanced stage (LAS) and more advanced stage (MAS) of Atlantic Rain Forest regeneration (Santos, 2014).

\begin{tabular}{|c|c|c|c|c|c|c|}
\hline \multirow{3}{*}{ Ecosystem } & \multicolumn{6}{|c|}{ Tree community attributes } \\
\hline & \multirow{2}{*}{$\mathbf{N i}$} & \multirow{2}{*}{$\mathbf{R}$} & \multirow{2}{*}{$\mathbf{U}$} & \multirow{2}{*}{$\mathbf{H}^{\prime}$} & BA & RPC \\
\hline & & & & & $\mathbf{m}^{3}$ & $\%$ \\
\hline LAS & 149 & 61 & 0.68 & 3.41 & 2.90 & 4 \\
\hline \multirow[t]{4}{*}{ MAS } & 82 & 43 & 0.74 & 3.25 & 4.97 & 19 \\
\hline & \multicolumn{6}{|c|}{ Soil attributes } \\
\hline & $\mathbf{P}$ & $\mathbf{K}$ & $\mathbf{C a}$ & Mg & \multirow{2}{*}{ pH } & SM \\
\hline & $\begin{array}{c}\mathrm{mg} \\
\mathrm{dm}^{-3}\end{array}$ & \multicolumn{3}{|c|}{---cmol $\mathrm{kg}^{-1}---$} & & $\%$ \\
\hline & \multicolumn{6}{|c|}{$0-5 \mathrm{~cm}$} \\
\hline LAS & $1.50^{\mathrm{a}}$ & $0.28^{\mathrm{b}}$ & $3.05^{\mathrm{a}}$ & $2.02^{\mathrm{a}}$ & $4.46^{\mathrm{b}}$ & $20.71^{\mathrm{b}}$ \\
\hline \multirow[t]{2}{*}{ MAS } & $1.96^{\mathrm{a}}$ & $0.46^{\mathrm{a}}$ & $3.68^{\mathrm{a}}$ & $2.33^{\mathrm{a}}$ & $5.11^{\mathrm{a}}$ & $32.94^{\mathrm{a}}$ \\
\hline & \multicolumn{6}{|c|}{$5-10 \mathrm{~cm}$} \\
\hline LAS & $0.63^{\mathrm{b}}$ & $0.22^{\mathrm{b}}$ & $1.47^{\mathrm{a}}$ & $1.51^{\mathrm{b}}$ & $4.16^{\mathrm{b}}$ & $20.10^{\mathrm{b}}$ \\
\hline MAS & $1.17^{\mathrm{a}}$ & $0.29^{\mathrm{a}}$ & $2.08^{\mathrm{a}}$ & $1.88^{\mathrm{a}}$ & $4.82^{\mathrm{a}}$ & $27.57^{\mathrm{a}}$ \\
\hline
\end{tabular}

Values in the column, in the same soil depth, followed by the same letter are not significantly different at $\mathrm{P}=0.05$, according to the Tukey test. Ni: number of individuals; R: richness; $\mathrm{U}$ : index of evenness; H': Sahnnon index of diversity; BA: basal area; RPC: relative participation of climax species; SM: soil moisture by gravimetric method.

According to Santos (2014), the more favorable edaphic conditions (higher values of $\mathrm{pH}$, available $\mathrm{P}$, exchangeable $\mathrm{K}$ and $\mathrm{Mg}$, and soil moisture content) in MAS occurred because of the relief, even though it influenced the differences between the areas in terms of the stage of natural forest regeneration (Table 1). We installed one plot $(20 \times 30 \mathrm{~m})$ in each different hill slope position (shoulder, backslope and footslope) in both LAS and MAS areas (totaling three plots in each area). Soil mesofauna and macrofauna were sampled by means of eight pitfall traps randomly installed in each plot, at least $10 \mathrm{~m}$ apart from each other (totaling 24 pitfall traps in each area). Each trap was considered an experimental unit. Traps consisted of plastic containers (17 cm deep, $9.7 \mathrm{~cm}$ diameter) filled with $100 \mathrm{~mL}$ of a $1 \%$ formaldehyde solution with three drops of detergent, that were buried in the forest floor with the opening near to the interface with litter. The traps remained in the field for 10 consecutive days in both LAS and MAS areas, at the end of the dry season (October/2012) and the rainy season (April/2013).

The arthropods caught in each trap were filtered through a funnel and transferred to a Petri dish, with the aid of a squeeze with distilled water. Then, the arthropods were stored in marked, small plastic containers $(10 \mathrm{~mL})$ with a solution of ethyl alcohol $70 \%$ for subsequent evaluation. The soil organisms were quantified and categorized into taxonomic groups (order or family) and functional groups (trophic guilds) (CSIRO, 1991). Total abundance, abundance of both taxonomic groups and functional groups (number of individuals trap ${ }^{-1}$ day $^{-1}$ ), richness ( $R$, total number of groups), evenness (U, Pielou index), and diversity $(\mathrm{H}$, Shannon index) were estimated. Menezes et al. (2009) and Machado et al. (2015) have previously evaluated the effect of the stage of forest regeneration on soil arthropod community in Pinheiral, by means of hand sorting from soil monoliths (Anderson \& Ingram, 1993) and pitfall traps, respectively. However, both of them occurred in different areas from the present work.

In order to correlate the soil fauna community with the accumulated leaf litter lying on the forest floor, 10 samples of this material were randomly collected within a $0.25 \mathrm{~m} \times 0.25 \mathrm{~m}\left(0.0625 \mathrm{~m}^{2}\right)$ wooden quadrat at each plot, both in the dry and rainy seasons. In the laboratory, samples were packaged in plastic bags and placed in a $2.0 \mathrm{~mm}$ mesh sieve to remove soil particles and organic matter at advanced stages of decomposition. Then, they were dried in a forced air oven $\left(65^{\circ} \mathrm{C}, 72 \mathrm{~h}\right)$ to obtain the dry weight and to estimate the dry mass of the total leaf litter standing stock (LSS; $\mathrm{Mg} \mathrm{ha}^{-1}$ ). Thereafter, the material was ground in a Wiley mill (mesh $<2 \mathrm{~mm}$ ) and digested for determining $\mathrm{N}, \mathrm{P}, \mathrm{K}, \mathrm{Ca}$, and $\mathrm{Mg}$ concentrations (Tedesco et al., 1995).

The values of total abundance, abundance of the taxonomic groups and functional groups, leaf litter standing stock, and nutrient concentrations were subjected to analysis of variance and the averages for the areas with different stages of natural forest regeneration were compared using the Mann-Whitney non-parametric test at 5\% significance, with BioEstat statistical 5.3 software version (Mamirauá Institute, Belém, Brazil). The principal component analysis (PCA) was also performed to identify the taxonomic groups that could be used to differentiate or indicate similarities between the forest fragments at different stages of natural regeneration, within the climatic seasons, considering the leaf litter attributes. Thus, we only considered the average abundance of the taxonomic groups and the leaf litter standing stock attributes that presented correlation coefficients up 
to $0.70 \%$ with the axis 1 or the axis 2 . We processed this multivariate analysis by using the PAST software (Hammer et al., 2001).

\section{RESULTS}

The captured soil organisms were classified in five functional groups: saprophagous/predator (S/P: Acari, Coleoptera, Formicidae, Isoptera, larvae of Coleoptera, larvae of Diptera, larvae of Lepidoptera, and Thysanoptera), microphagous/saprophagous (M/S: Collembola), herbivorous (H: Auchenorrhyncha, Diptera, Heteroptera, and Orthoptera), predator (P: Araneae, Chilopoda, Hymenoptera, Opilionida, and Pseudoscorpionida), and saprophagous (S: Blattodea, Dermaptera, Diplopoda, Diplura, Isopoda, Psocoptera, and Symphyla). In the study area, 14,781 organisms were sampled in total, which corresponded to $370 \pm 27$ individuals trap ${ }^{-1} \mathrm{~d}^{-1}$. Most of them (8,831 individuals; $60 \%$ ), occurred in MAS and the other part (5,975 individuals; 40\%), in LAS. Thus, total abundance was higher in MAS compared with LAS, during both dry and rainy seasons (Table 2).

There were no differences between the different stages of natural forest regeneration neither for the abundance of microphagous/saprophagous nor for the herbivorous abundance, in both climatic seasons. The same pattern was observed in relation to predators and saprophagous, during the rainy season. However, the effect of the forest regeneration stage was observed when considering the relative participation of these functional groups. The relative participation of herbivorous decreased as the natural forest regeneration advanced, both in the dry season (from $21 \%$ in LAS to $17 \%$ in MAS) and in rainy season (from $15 \%$ in LAS to $9 \%$ in MAS). This reduction in the relative participation throughout the forest regeneration also occurred during the rainy season for microphagous/saprophagous (from 68\% in LAS to $40 \%$ in MAS) and predators (from $4 \%$ in LAS to $2 \%$ in MAS).

The soil organisms were distributed in 25 taxonomic groups. Most of them (16 groups) occurred in both stages of natural forest regeneration, at least in one of the climatic seasons: Acari, Araneae, Auchenorryncha, Collembola, Coleoptera, Dermaptera, Diplura, Diptera, Formicidae, Heteroptera, Hymenoptera, Isopoda, Opilionida, Orthoptera, Pseudoscorpionida, and Psocoptera. Six taxonomic groups presented restricted occurrence. Isoptera and larvae of Lepidoptera, both in the dry season, and Thysanoptera, in the rainy season, were sampled only in LAS. On the other hand, Blattodea, Diplopoda, Coleoptera larvae, and Symphyla occurred only in MAS, in the rainy season. The taxonomic groups that presented very low relative participation (less than $2 \%$ ) were reunited and classified as "Others" (Table 3). Auchenorryncha, Dermaptera, Heteroptera, and Hymenoptera belonged to Others in the two stages of forest regeneration, during both climatic seasons.

Only seven of these taxonomic groups were responsible for more than $95 \%$ of all sampled individuals: Acari, Araneae, Collembola, Coleoptera, Diptera, Formicidae, and Orthoptera (Figure 1). Among them, Collembola and Formicidae were predominant in LAS and MAS, respectively, regardless of the climatic season. The relative participation of Acari, Araneae, Coleoptera, Diptera, others (both climatic seasons), and Collembola (rainy season) decreased as the level of natural forest regeneration progressed (Figure 1). The opposite pattern occurred for Formicidae, as previously mentioned, and for Orthoptera, where relative

Table 2. Average abundance (individual trap ${ }^{-1}$ day $^{-1}$ ) of the soil arthropod functional groups in the less advanced stage (LAS) and more advanced stage (MAS) of Atlantic Rain Forest regeneration, during the dry and rainy seasons ${ }^{*}$

\begin{tabular}{|c|c|c|c|c|}
\hline \multirow{2}{*}{ Functional group } & LAS & MAS & LAS & MAS \\
\hline & \multicolumn{2}{|c|}{ Dry season } & \multicolumn{2}{|c|}{ Rainy season } \\
\hline $\mathrm{S} / \mathrm{P}$ & $5.06^{\mathrm{b}}(0.76)$ & $6.25^{\mathrm{a}}(2.71)$ & $1.40^{\mathrm{b}}(0.26)$ & $11.33^{\mathrm{a}}(4.24)$ \\
\hline $\mathrm{M} / \mathrm{S}$ & $3.78^{\mathrm{a}}(0.41)$ & $4.25^{\mathrm{a}}(0.57)$ & $8.38^{\mathrm{a}}(1.41)$ & $9.34^{\mathrm{a}}(1.72)$ \\
\hline $\mathrm{H}$ & $2.62^{\mathrm{a}}(0.33)$ & $2.29^{\mathrm{a}}(0.38)$ & $1.80^{\mathrm{a}}(0.31)$ & $2.13^{\mathrm{a}}(0.42)$ \\
\hline $\mathrm{P}$ & $0.69^{\mathrm{a}}(0.10)$ & $0.33^{\mathrm{b}}(0.07)$ & $0.52^{\mathrm{a}}(0.12)$ & $0.35^{\mathrm{a}}(0.07)$ \\
\hline $\mathrm{S}$ & $0.25^{\mathrm{a}}(0.04)$ & $0.13^{\mathrm{b}}(0.02)$ & $0.31^{\mathrm{a}}(0.11)$ & $0.37^{\mathrm{a}}(0.18)$ \\
\hline Total & $12.40^{\mathrm{b}}(0.55)$ & $13.26^{\mathrm{a}}(1.32)$ & $12.41^{\mathrm{b}}(0.89)$ & $23.52^{\mathrm{a}}(2.24)$ \\
\hline
\end{tabular}

${ }^{*}$ Average of 24 replications in each area. Values of average abundance (standard error) in the line, in the same climatic season, followed by the same letter are not significantly different at $\mathrm{P}=0.05$, according to the Mann-Whitney test. S/P: Saprophagous/ Predator; M/S: Microphagous/Saprophagous; H: Herbivorous; P: Predator; S: Saprophagous. 


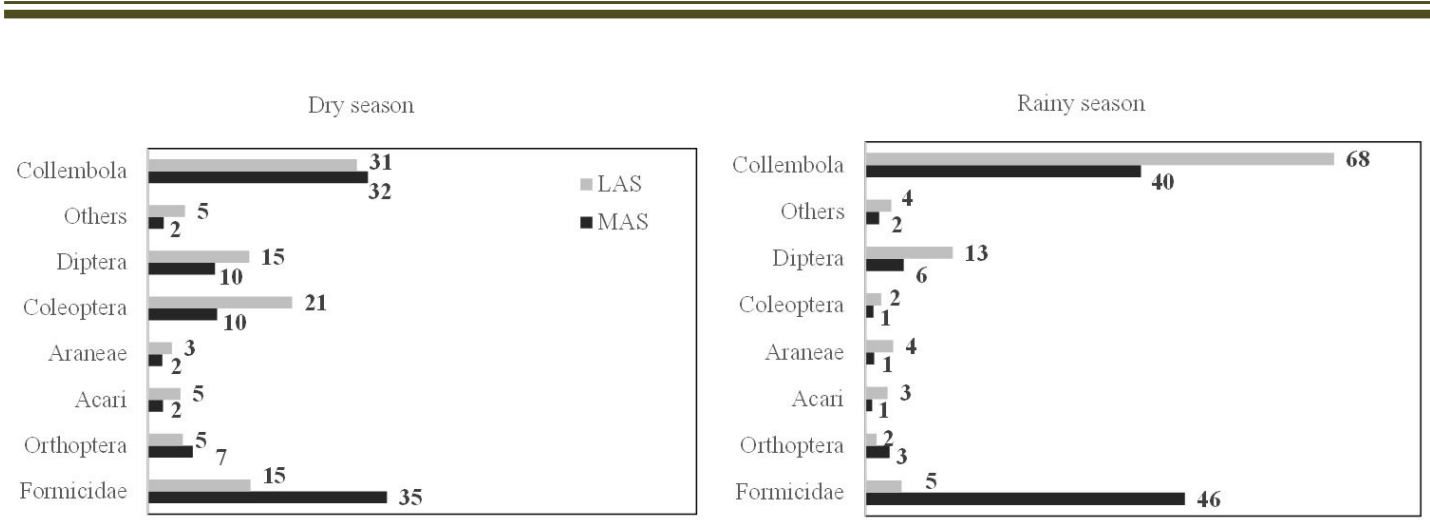

Figure 1. Relative participation (\%) of the soil arthropod taxonomic groups in the less advanced stage (LAS) and more advanced stage (MAS) of Atlantic Rain Forest regeneration, during the dry and rainy seasons.

Table 3. Distribution of the soil arthropod taxonomic groups classified as "Others" in the less advanced stage (LAS) and more advanced stage (MAS) of Atlantic Rain Forest regeneration, during the dry and rainy seasons.

\begin{tabular}{c|cl} 
Ecosystem & Season & \multicolumn{1}{c}{ Taxonomic group } \\
\hline LAS & Dry & $\begin{array}{l}\text { Auchenorryncha, Dermaptera, Heteroptera, Hymenoptera, Isopoda, Isoptera, larvae of } \\
\text { Lepidoptera, Opilionida, Pseudoscorpionida and Psocoptera }\end{array}$ \\
& Rainy & $\begin{array}{l}\text { Auchenorryncha, Chilopoda, Dermaptera, Diplura, Heteroptera, Hymenoptera, } \\
\text { Isopoda, Isoptera, larvae of Diptera, Orthoptera, Psocoptera and Thysanoptera }\end{array}$ \\
Auchenorryncha, Dermaptera, Heteroptera, Hymenoptera, Opilionida and \\
MAS
\end{tabular}

participation increased throughout the process of the natural forest regeneration (both climatic seasons).

We observed the significant influence of the stage of natural forest regeneration only for some taxonomic groups. In the dry season, the values of abundance of Acari (LAS: $0.59 \pm 0.13$ individual trap $^{-1}$ day $^{1}$; MAS: $0.29 \pm 0.09$ ), Araneae (LAS: $0.43 \pm 0.07$ individual trap $^{-1}$ day $^{-1}$; MAS: $0.28 \pm 0.06$ ), Coleoptera (LAS: $2.61 \pm 0.42$ individual trap $^{-1}$ day $^{-1}$; MAS: $\left.1.34 \pm 0.28\right)$, and Dermaptera (LAS: $0.18 \pm 0.03$ individual trap ${ }^{-1}$ day $^{-1}$; MAS: $0.08 \pm 0.02$ ) were significantly higher in LAS. On the other hand, the abundance of Formicidae was higher in the MAS in the rainy season (MAS: $10.82 \pm 4.16$ individual trap ${ }^{-1}$ day $^{-1}$; LAS: $0.65 \pm 0.15$ ).

In general, the values of richness, diversity (both in the dry season), and evenness (in both climatic seasons) were higher in LAS in comparison with MAS (Table 4). In terms of the attributes of the leaf litter standing stock, no consistent pattern was observed between the two stages of forest regeneration by means of $\mathrm{N}, \mathrm{P}, \mathrm{K}$ and $\mathrm{Mg}$ concentrations. However, the LSS
Table 4. Structural attributes of the soil arthropod community in the less advanced stage (LAS) and more advanced stage (MAS) of Atlantic Rain Forest regeneration, during the dry and rainy seasons ${ }^{*}$.

\begin{tabular}{ccccccc} 
Structural & & LAS & MAS & & LAS & MAS \\
\cline { 2 - 3 } \cline { 5 - 6 } attribute & \multicolumn{2}{c}{ Dry season } & & \multicolumn{2}{c}{ Rainy season } \\
R & 17 & 13 & & 18 & 20 \\
U & 0.68 & 0.65 & & 0.44 & 0.42 \\
H' & 2.77 & 2.39 & & 1.82 & 1.82 \\
\hline
\end{tabular}

*Average of 24 replications in each area. R: richness; U: eveness; $\mathrm{H}$ : diversity.

dry mass was higher in LAS during both climatic seasons, whereas $\mathrm{Ca}$ concentrations were higher in MAS in both climatic seasons (Table 5).

In the principal component analysis graphic, the variables (taxonomic group abundance and the attributes of the leaf litter standing stock) were divided into two axes (60.61\% for axis 1 and $26.74 \%$ for axis 2 ) that explained $87.35 \%$ of the total variability between the different stages of natural forest regeneration, during the climatic seasons (Figure 2). Along the axis 
Table 5. Leaf litter standing stock attributes in the less advanced stage (LAS) and more advanced stage (MAS) of Atlantic Rain Forest regeneration, during the dry and rainy seasons*.

\begin{tabular}{|c|c|c|c|c|c|c|c|}
\hline \multirow{2}{*}{ Season } & \multirow{2}{*}{ Ecosystem } & LSS & $\mathbf{N}$ & $\mathbf{P}$ & $\mathbf{K}$ & $\mathrm{Ca}$ & Mg \\
\hline & & $\left(\mathrm{Mg} \mathrm{ha}^{-1}\right)$ & \multicolumn{5}{|c|}{ 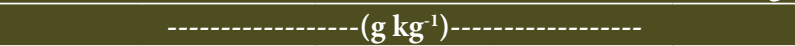 } \\
\hline \multirow{2}{*}{ Dry } & LAS & $\begin{array}{c}10.22^{\mathrm{a}} \\
(3.38)\end{array}$ & $\begin{array}{l}13.70^{\mathrm{a}} \\
(3.56)\end{array}$ & $\begin{array}{c}0.65^{\mathrm{a}} \\
(0.28)\end{array}$ & $\begin{array}{c}0.37^{\mathrm{a}} \\
(0.12)\end{array}$ & $\begin{array}{r}9.72^{\mathrm{a}} \\
(4.03)\end{array}$ & $\begin{array}{r}4.19^{\mathrm{a}} \\
(1.78)\end{array}$ \\
\hline & MAS & $\begin{array}{r}6.47^{\mathrm{b}} \\
(2.03)\end{array}$ & $\begin{array}{l}11.40^{\mathrm{b}} \\
(3.06)\end{array}$ & $\begin{array}{c}0.67^{\mathrm{a}} \\
(0.17)\end{array}$ & $\begin{array}{c}0.43^{\mathrm{a}} \\
(0.19)\end{array}$ & $\begin{array}{l}21.00^{\mathrm{b}} \\
(8.90)\end{array}$ & $\begin{array}{r}5.86^{\mathrm{b}} \\
(2.29)\end{array}$ \\
\hline \multirow{2}{*}{ Rainy } & LAS & $\begin{array}{r}7.45^{\mathrm{a}} \\
(2.53)\end{array}$ & $\begin{array}{l}12.76^{\mathrm{a}} \\
(1.82)\end{array}$ & $\begin{array}{r}0.64^{\mathrm{a}} \\
(0.14)\end{array}$ & $\begin{array}{r}0.50^{\mathrm{a}} \\
(0.17)\end{array}$ & $\begin{array}{r}9.11^{\mathrm{a}} \\
(3.73)\end{array}$ & $\begin{array}{r}5.74^{\mathrm{a}} \\
(1.55)\end{array}$ \\
\hline & MAS & $\begin{array}{r}5.04^{\mathrm{b}} \\
(2.63) \\
\end{array}$ & $\begin{array}{l}15.21^{\mathrm{b}} \\
(2.18)\end{array}$ & $\begin{array}{r}1.06^{\mathrm{b}} \\
(1.86) \\
\end{array}$ & $\begin{array}{c}0.31^{\mathrm{b}} \\
(0.11)\end{array}$ & $\begin{array}{r}21.27^{b} \\
(6.75)\end{array}$ & $\begin{array}{r}4.79^{\mathrm{b}} \\
(1.12)\end{array}$ \\
\hline
\end{tabular}

${ }^{*}$ Average of 30 replicates in each area. Average values (standard deviation) in the column, in the same climatic season, followed by the same letter are not significantly different at $\mathrm{P}=0.05$, according to the Mann-Whitney test. LSS: dry mass of the total leaf litter standing stock; N, P, K, Ca and Mg: concentration of these nutrients in the leaf litter standing stock.

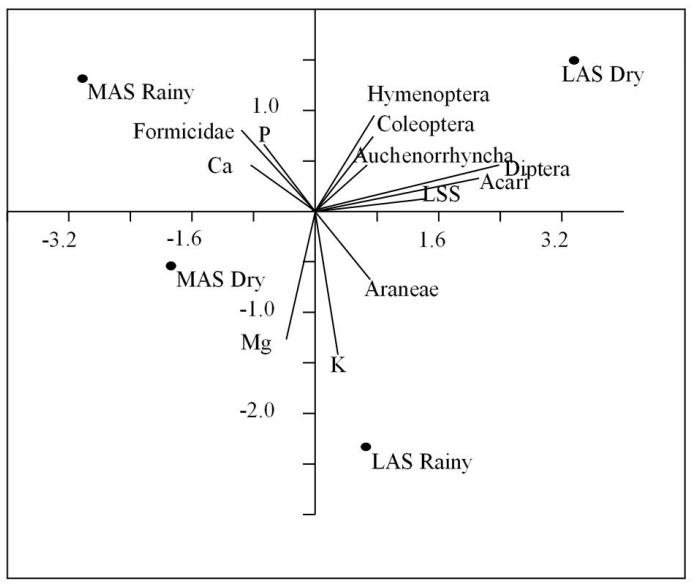

Figure 2. Principal component analysis of the abundance of the soil arthropod taxonomic groups and leaf litter standing stock attributes in the less advanced stage (LAS) and more advanced stage (MAS) of Atlantic Rain Forest regeneration, during the dry and rainy seasons. LSS: dry mass of the leaf litter standing stock; $\mathrm{P}, \mathrm{K}, \mathrm{Ca}$ and $\mathrm{Mg}$ : concentration of these nutrients in the leaf litter standing stock.

1 (main axis), it can be easily noticed that the natural stages of forest regeneration were separated from each other. The abundance of the most soil fauna organisms, dry mass and $\mathrm{K}$ concentration of the leaf litter standing stock were correlated to LAS though restricted to the right portion of the graphic. Whereas Formicidae and concentrations of $\mathrm{P}, \mathrm{Ca}$, and $\mathrm{Mg}$ in the leaf litter standing stock were correlated to MAS and restricted within the left portion of the graphic, along the two climatic seasons.

Most of the taxonomic groups (Acari, Auchenorryncha, Coleoptera, Diptera, and Hymenoptera) were correlated to the stage of forest regeneration and climatic season (LAS Dry) because of the increased leaf litter standing stock (Figure 2). Araneae was correlated to the K concentration in the leaf litter standing stock in LAS, in the rainy season. On the other hand, in MAS only Formicidae was correlated to the leaf litter attributes ( $\mathrm{P}$ and $\mathrm{Ca}$ concentration in the leaf litter standing stock), in the rainy season. None of the taxonomic groups correlated to MAS, in the dry season.

\section{DISCUSSION}

The higher total abundance of the soil arthropod community in the MAS was a consequence of the higher abundance of the saprophagous/predator group in the MAS, in both climatic seasons. This in turn reflected the higher relative participation of Formicidae in MAS, in comparison with LAS. In fact, Formicidae was the only group that presented higher abundance in MAS (rainy season), when compared to LAS. Formicidae also presented increased abundance/density along the development of forest regeneration in a Mexican Cloud Forest (Negrete-Yankelevich et al., 2007) and of Atlantic Rain Forest in the understorey of abandoned eucalyptus plantations (Camara et al., 2012). By contrast, the abundance of both predator and saprophagous groups were higher in LAS in comparison to MAS, in the dry season. The presence of different groups of predators and saprophagous indicates that the ecosystem presents high structural complexity, functional redundancy and redistribution of energy along the food chain (Begon et al., 2005; Menezes et al., 2009). 
Collembola, which was the first and second group with higher relative participation in LAS and MAS, respectively, was also predominant at different stages of the Atlantic forest regeneration, under eucalyptus plantations (Camara et al., 2012) and in secondary forest fragments in Pinheiral (Machado et al., 2015). Most of the individuals that represent Formicidae are usually restricted to the nest and thus any method of soil fauna sampling tends to underestimate the population density values for this group (Correia \& Oliveira, 2000). Despite this, Formicidae is often one of the most abundant soil taxonomic groups in different forest ecosystems (Moço et al., 2005; Copatti \& Daudt, 2009; Menezes et al., 2009; Morais et al., 2010; Rousseau et al., 2014), regardless the soil fauna sampling method (Sabu \& Shiju, 2009).

In contrast to the present study, Negrete-Yankelevich et al. (2007), Menezes et al. (2009), Camara et al. (2012), Rousseau et al. (2014), and Machado et al. (2015) reported the increased abundance of Araneae, Coleoptera, and Dermaptera as the stage of tropical forest regeneration progressed. In relation to Formicidae, the abundance of this group was favored in both less (Menezes et al., 2009; Camara et al., 2012) and more advanced stages of tropical forest regeneration (Machado et al., 2015).
The set of results obtained in the present study indicated that eight taxonomic groups (Acari, Araneae, Coleoptera, Dermaptera, Diptera, Isoptera, larvae of Lepidoptera, and Thysanoptera), which were distributed in a wider range of functional groups (predator, saprophagous, herbivorous, and microphagous/saprophagous), were somehow favored in LAS. In general, this fact influenced higher values of both richness and evenness, which in turn led to greater diversity in LAS. On the other hand, only two taxonomic groups, Formicidae (saprophagous/predator) and Orthoptera (herbivorous), were favored in MAS, which influenced lower values of evenness in this ecosystem. Thus, we observed the effect of the stage of natural forest regeneration on the structure and composition of the soil arthropod communities, in areas of Seasonal Semideciduous Forest at Pinheiral.

The values for total abundance/density and richness generally increased over the course of the natural regeneration of subtropical and tropical forests in different sites (Table 6). Our results corroborated this fact only in relation to the total abundance. The higher complexity of the soil fauna community is a consequence of the higher structure of the plant community in advanced stages of natural forest regeneration, in comparison

Table 6. Structural attributes of the soil arthropods in different stages of natural regeneration of Tropical Forests.

\begin{tabular}{|c|c|c|c|c|}
\hline Site & Ecosystem & $\begin{array}{l}\text { Age (years)/Stage of } \\
\text { regeneration }\end{array}$ & $\mathbf{A b} / \mathbf{D}$ & $\mathbf{R}$ \\
\hline Puerto Rico & Tropical Wet Forest $\mathrm{t}^{1}$ & $5 ; 30 ;>60$ & - & $7-10 ; 15-21 ; 18-26$ \\
\hline Mexico & $\begin{array}{l}\text { Tropical Montane } \\
\text { Cloud Forest }^{2}\end{array}$ & $15 ; 45 ; 75 ; 100$ & $\begin{array}{l}16.6 ; 28.7 ; 52.6 \\
54.9 \text { ind. } \mathrm{m}^{-2}\end{array}$ & - \\
\hline \multirow[t]{8}{*}{ Brazil } & Amazonian Forest ${ }^{3}$ & $\begin{array}{l}\text { Secondary forest; primary } \\
\text { forest }\end{array}$ & 29,$776 ; 7,168$ ind. $\mathrm{m}^{-2}$ & $21 ; 13$ \\
\hline & Amazonian Forest ${ }^{4}$ & $\begin{array}{l}\text { Young (4-7); medium (11-15); } \\
\text { old secondary forests }(20-40) \text {; } \\
\text { old-growth forest }\end{array}$ & $\begin{array}{c}1,191 ; 1,374 ; \\
2,221 ; 1,758 \text { ind. } m^{-2}\end{array}$ & $15.1 ; 15.3 ; 17.4 ; 16.1$ \\
\hline & Atlantic Forest ${ }^{5 *}$ & $\begin{array}{c}\mathrm{YP}^{\star *}(19) ; \mathrm{MP}^{\star *}(42) \\
\text { native forest }\end{array}$ & $\begin{array}{c}13.5 ; 20.6 \\
25.5 \text { ind. pitfall }{ }^{-1} \text { day }^{-1}\end{array}$ & $19 ; 20 ; 23$ \\
\hline & Atlantic Forest ${ }^{6}$ & $6 ; 15 ; 35 ; 70 ; 130 ; 300$ & $\begin{array}{c}165 ; 110 ; 178 ; 223 ; 195 \\
243 \text { ind. }\end{array}$ & $5 ; 6 ; 9 ; 10 ; 11 ; 12$ \\
\hline & Atlantic Forest ${ }^{7 \star}$ & $\mathrm{LAS}^{* * *} ; \mathrm{MAS}^{* * *}$ & $\begin{array}{c}12.41 \\
18.39 \text { ind. pitfall } \\
\end{array}$ & $18 ; 17$ \\
\hline & Atlantic Forest ${ }^{8 *}$ & Initial; medium; advanced stage & $1941 ; 1384 ; 2156$ ind. $\mathrm{m}^{-2}$ & $16 ; 18 ; 20$ \\
\hline & Atlantic Forest $^{9 *}$ & Initial; medium; advanced stage & $9.54 ; 18.28 ; 25.53$ & $19 ; 20 ; 22$ \\
\hline & $\begin{array}{l}\text { Cerrado Seasonal } \\
\text { Forest }^{10}\end{array}$ & Initial; mature & 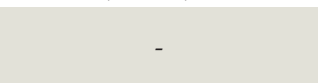 & $13 ; 19$ \\
\hline
\end{tabular}

Ab/D: abundance/density; R: richness. ${ }^{1}$ Barberena-Arias \& Aide (2003); ${ }^{2}$ Negrete-Yankelevich et al. (2007); ${ }^{3}$ Morais et al. (2010); ${ }^{4}$ Rousseau et al. (2014); ${ }^{5}$ Camara et al. (2012); ${ }^{6}$ Szinwelski et al. (2012); ${ }^{7}$ Present study, ${ }^{8}$ Menezes et al. (2009); ${ }^{9}$ Machado et al. (2015); ${ }^{10}$ Cunha \& Orlando (2011); ${ }^{*}$ average values between rainy and dry seasons; ${ }^{* *}$ Atlantic Forest regeneration under abandoned young (YP) and mature (MP) plantations of Corymbia citriodora; ${ }^{* * *}$ LAS: less advanced stage; MAS: more advanced stage of natural forest regeneration. 
with initial stages of tropical forest regeneration (Negrete-Yankelevich et al., 2007; Menezes et al., 2009; Camara et al., 2012; Szinwelski et al., 2012; Rousseau et al., 2014; Machado et al., 2015). However, in terms of the effect of the natural forest regeneration stage on evenness and diversity of soil fauna community, the literature presented divergent data.

The variability in the estimates of soil fauna structure is probable due to the employment of different extraction methods to recover these animals (Stork \& Eggleton, 1992). Camara et al. (2012), Szinwelski et al. (2012), Machado et al. (2015), and the present work captured the soil arthropods by means of pitfall traps. On the other hand, Negrete-Yankelevich et al. (2007), Menezes et al. (2009), and Rousseau et al. (2014) extracted the animals from soil monoliths according to the Anderson \& Ingram (1993) method. Other probable reason for this variation may be changes within one single climatic season a year, in comparison to the previous or next year. Thus, studies focusing on at least two consecutive years could help to refine the results.

The higher leaf litter standing stock contributed to a soil fauna community with greater complexity in LAS, especially during the dry season. According to Santos (2014), lower gravimetric moisture in the surface soil $(0-10 \mathrm{~cm})$ of LAS slowed litter decomposition and thus favored a higher accumulation of leaf litter standing stock on the forest floor in this ecosystem, when compared with MAS. Higher leaf litter standing stock promotes a more suitable microclimate with lower light intensity and, consequently, lower temperatures, which favors the reproduction and survival of the soil fauna organisms in tropical ecosystems (Davis et al., 2003; Negrete-Yankelevich et al., 2007; Szinwelski et al., 2012). This importance of the leaf litter standing stock was more evident during the dry season, when the higher leaf litter standing stock can minimize the drastic fluctuations in soil temperature and the decreasing in soil moisture (Facelli et al., 1999; Wolkovich, 2010).

Furthermore, Santos (2014) considered that the tree community in LAS presented higher values of richness and diversity. This fact may have also influenced the higher complexity of the soil fauna in this ecosystem, because higher plant diversity may support a soil fauna community with richer, more diverse taxonomic groups (Moço et al., 2005; Menezes et al., 2009; Machado et al., 2015). Tropical forests with higher tree diversity present more heterogeneous leaf litter, which implies a more varied food resource for soil fauna (Negrete-Yankelevich et al., 2007; Correia \& Andrade, 2008). Thus, similarity of the soil fauna community between areas with secondary forest and areas with mature native forest increases as the process of natural forest regeneration develops (Davis et al., 2003; Camara et al., 2012).

\section{CONCLUSIONS}

The abundance of the soil arthropod community was greater in the area at a more advanced stage of natural Atlantic Forest regeneration, due to the higher abundance of Formicidae. On the other hand, richness, uniformity, and diversity were higher in the area at a less advanced stage of forest regeneration, mainly influenced by the higher dry mass of the leaf litter standing stock.

The soil arthropod community acted as a good bioindicator. Acari, Araneae, Coleoptera, Collembola, Dermaptera, Diptera, Isoptera, larvae of Lepidoptera, and Thysanoptera were favored in the area at a less advanced stage of natural Atlantic Forest regeneration. By contrast, Blattodea, Diplopoda, Formicidae, larvae of Coleoptera, Orthoptera, and Symphyla were favored in the more advanced stage of forest regeneration.

\section{SUBMISSION STATUS}

Received: 12 nov., 2016

Accepted: 12 jan., 2017

\section{CORRESPONDENCE TO}

\section{Marcos Gervasio Pereira}

Departamento de Solos, Universidade Federal Rural do Rio de Janeiro - UFRRJ, BR 465, Km 7, CEP 23890-000, Seropédica, RJ, Brazil e-mail: mgervasiopereira01@gmail.com

\section{REFERENCES}

Anderson JM, Ingram JS. Tropical soil biology and fertility: a handbook of methods. 2nd ed. Wallingford: CAB International; 1993. 221 p.

Barberena-Arias MF, Aide TM. Species diversity and trophic composition of litter insects during plant 
secondary succession. Caribbean Journal of Science 2003; 39(2): 161-169.

Begon M, Townsend CR, Harper JL. Ecology: from individuals to ecosystems. Malden: Blackwell Publishing; 2005. 759 p.

Caldas AJFS, Francelino MR. Fragmentação florestal na Serra da Concórdia, Vale do Paraíba: caracterização como subsídio à preservação da Mata Atlântica. Floresta e Ambiente 2009; 16(2): 8-19.

Camara R, Correia MEF, Villela DM. Effects of eucalyptus plantations on soil arthropod communities in a Brazilian Atlantic Forest conservation. Bioscience Journal 2012; 28(3): 445-455.

Commonwealth Scientific and Industrial Research Organisation - CSIRO. The insects of Australia: a textbook for students and research workers. 2 ed. Vol. 1, 2. New York: Cornell University Press; 1991. 1137 p.

Copatti CE, Daudt CR. Diversidade de artrópodes na serapilheira em fragmentos de mata nativa e Pinus elliottii (Engelm. var elliottii). Ciência e Natura 2009; 31(1): 95-113.

Correia MEF, Andrade AG. Formação de serapilheira e ciclagem de nutrientes. In: Santos GA, Camargo FAO, editores. Fundamentos da matéria orgânica do solo: ecossistemas tropicais e subtropicais. Porto Alegre: Gênesis; 2008. p. 137-170

Correia MEF, Oliveira LCM. Fauna de solo: aspectos gerais e metodológicos. Seropédica: Centro Nacional de Pesquisa de Agrobiologia; 2000. 46 p. (Documentos, no. 112).

Cunha HF, Orlando TYS. Functional composition of termite species in areas of abandoned pasture and in secondary succession of the Parque Estadual Altamiro de Moura Pacheco, Goiás, Brazil. Bioscience Journal 2011; 27(6): 986-992

Davis ALV, van Aarde RJ, Scholtz CH, Delport JH. Convergence between dung beetle assemblages of a post-mining vegetational chronosequence and unmined dune forest. Restoration Ecology 2003; 11(1): 29-42. http:// dx.doi.org/10.1046/j.1526-100X.2003.00133.x.

Facelli JM, Williams R, Fricker S, Ladd B. Establishment and growth of seedlings of Eucalyptus obliqua: interactive effects of litter, water, and pathogens. Australian Journal of Ecology 1999; 24(5): 484-494. http://dx.doi.org/10.1046/ j.1440-169x.1999.00988.x.

Guariguata MR, Ostertag R. Neotropical secondary succession: changes in structural and functional characteristics. Forest Ecology and Management 2001; 148(1-3): 185-206. http:// dx.doi.org/10.1016/S0378-1127(00)00535-1.

Hammer $\varnothing$, Harper DAT, Ryan PD. PAST: Paleontological statistics software package for education and data analysis. Palaeontologia Electronica [online]. 2001 [cited 2014 nov. 22]; 4(1): 1-9. Available from: http://palaeo-electronica. org/2001_1/past/issue1_01.htm

Köppen W. Climatologia: con un estudio de los climas de la Tierra. Mexico: Fondo de Cultura Economica; 1948. 479 p.
Machado DL, Pereira MG, Correia MEF, Diniz AR, Menezes CEG. Fauna edáfica na dinâmica sucessional da Mata Atlântica em floresta estacional semidecidual na bacia do Rio Paraíba do Sul - RJ. Ciência Florestal 2015; 25(1): 91-106. http://dx.doi.org/10.5902/1980509817466.

Menezes CEG. Integridade de paisagem, manejo e atributos do solo no Médio Vale do Paraíba do Sul, Pinheiral-RJ [tese]. Seropédica: Universidade Federal Rural do Rio de Janeiro; 2008.

Menezes CEG, Correia MEF, Pereira MG, Batista I, Rodrigues KM, Couto WH et al. Macrofauna edáfica em estádios sucessionais de floresta estacional semidecidual e pastagem mista em Pinheiral (RJ). Revista Brasileira de Ciência do Solo 2009; 33(6): 1647-1656. http://dx.doi. org/10.1590/S0100-06832009000600013.

Moço MKS, Gama-Rodrigues EF, Gama-Rodrigues AC, Correia MEF. Caracterização da fauna edáfica em diferentes coberturas vegetais na região norte fluminense. Revista Brasileira de Ciência do Solo 2005; 29(4): 555-564. http:// dx.doi.org/10.1590/S0100-06832005000400008.

Morais JW, Oliveira VS, Dambros CS, Tapia-Coral SC, Acioli ANS. Mesofauna do solo em diferentes sistemas de uso da terra no Alto Rio Solimões, AM. Neotropical Entomology 2010; 39(2): 145-152. PMid:20498948. http:// dx.doi.org/10.1590/S1519-566X2010000200001.

Negrete-Yankelevich S, Fragoso C, Newton AC, Heal OW. Successional changes in soil, litter and macroinvertebrate parameters following selective logging in a Mexican Cloud Forest. Applied Soil Ecology 2007; 35(2): 340-355. http:// dx.doi.org/10.1016/j.apsoil.2006.07.006.

Rousseau GX, Silva PRS, Celentano D, Carvalho CJR. Macrofauna do solo em uma cronosequência de capoeiras, florestas e pastos no Centro de Endemismo Belém, Amazônia Oriental. Acta Amazonica 2014; 44(4): 499512. http://dx.doi.org/10.1590/1809-4392201303245.

Sabu TK, Shiju RT. Efficacy of pitfall trapping, Winkler and Berlese extraction methods for measuring grounddwelling arthropods in moistdeciduous forests in the Western Ghats. Journal of Insect Science 2009; 10(98): 1-17. http://dx.doi.org/10.1673/031.010.9801.

Santos GL. Efeito da pedoforma no processo de sucessão secundária em fragmentos florestais na região do Médio Vale do Paraíba do Sul, Pinheiral, RJ [dissertação]. Seropédica: Universidade Federal Rural do Rio de Janeiro; 2014.

Siminski A, Mantovani M, Reis MS, Fantini AC. Sucessão florestal secundária no município de São Pedro de Alcântara, litoral de Santa Catarina: estrutura e diversidade. Ciência Florestal 2004; 14(1): 21-33. http:// dx.doi.org/10.5902/198050981778.

Snyder BA, Hendrix PF. Current and potential roles of soil macroinvertebrates (earthworms, millipedes and isopods) in ecological restoration. Restoration Ecology 2008; 16(4): 629-636. http://dx.doi.org/10.1111/j.1526100X.2008.00484.x 
Stork NE, Eggleton P. Invertebrates as determinants and indicators of soil quality. American Journal of Alternative Agriculture 1992; 7(1-2): 38-47.

Szinwelski N, Rosa CS, Schoereder J, Mews CM, Sperber CF. Effects of forest regeneration on crickets: evaluating environmental drivers in a 300-year chronosequence. International Journal of Zoology 2012; 2012: 1-13. http:// dx.doi.org/10.1155/2012/793419.
Tedesco MJ, Gianello C, Bissani CA, Bohnen H, Volkweiss SJ. Análises de solo, plantas e outros materiais. 2 ed. Porto Alegre: Universidade Federal do Rio Grande do Sul; 1995. 174 p. (Boletim técnico, no. 5).

Wolkovich EM. Nonnative grass litter enhances grazing arthropod assemblages by increasing native shrub growth. Ecology 2010; 91(3): 756-766. PMid:20426334. http:// dx.doi.org/10.1890/09-0147.1. 